\title{
Corporate Financial Leverage, Asset Utilization and Nonperforming Loans in Pakistan
}

\section{Ijaz Hussain*}

\begin{abstract}
This study applies panel least squares and fixed effects to a sample of 40 banks for the period 2006-14 to identify the key determinants of nonperforming loans (NPLs) in Pakistan. The findings suggest that, in addition to some macroeconomic and bank-specific variables, the corporate debt-equity ratio and financial burden have a positive, significant impact on NPLs, while corporate asset utilization and the diversification of bank activities significantly reduce the volume of NPLs. This has policy implications not only for the federal government, but also for bank managers, regulators and policy advisors.
\end{abstract}

Keywords: nonperforming loans, bank asset quality, diversification, Pakistan.

JEL classification: G00, G21, G28.

\section{An Overview of Nonperforming Loans in Pakistan}

Although the volume of nonperforming loans (NPLs) as a share of gross advances in Pakistan has declined from a peak of 16.2 percent in 2011, this ratio remains higher than the regional and world averages -12.5 percent in 2014 compared to 7.0 percent for South Asia and 4.5 percent globally (Figures 1 and 2). The State Bank of Pakistan reveals that lending to the corporate sector alone accounts for almost 65.6 percent of gross advances for investment in noncurrent assets, working capital and trade financing. The corporate sector's contribution to the total volume of NPLs was alarmingly high at almost 70 percent in 2014 (Table 1). More than 94 percent of all bank credit is channeled to urban areas. The share of rural areas has never been more than 6 percent (Table 2).

\footnotetext{
* Assistant Professor, School of Liberal Arts and Social Sciences, Beaconhouse National University, Lahore, Pakistan.
} 
Figure 1: NPLs as a percentage of gross advances for selected South Asian countries and regional aggregates

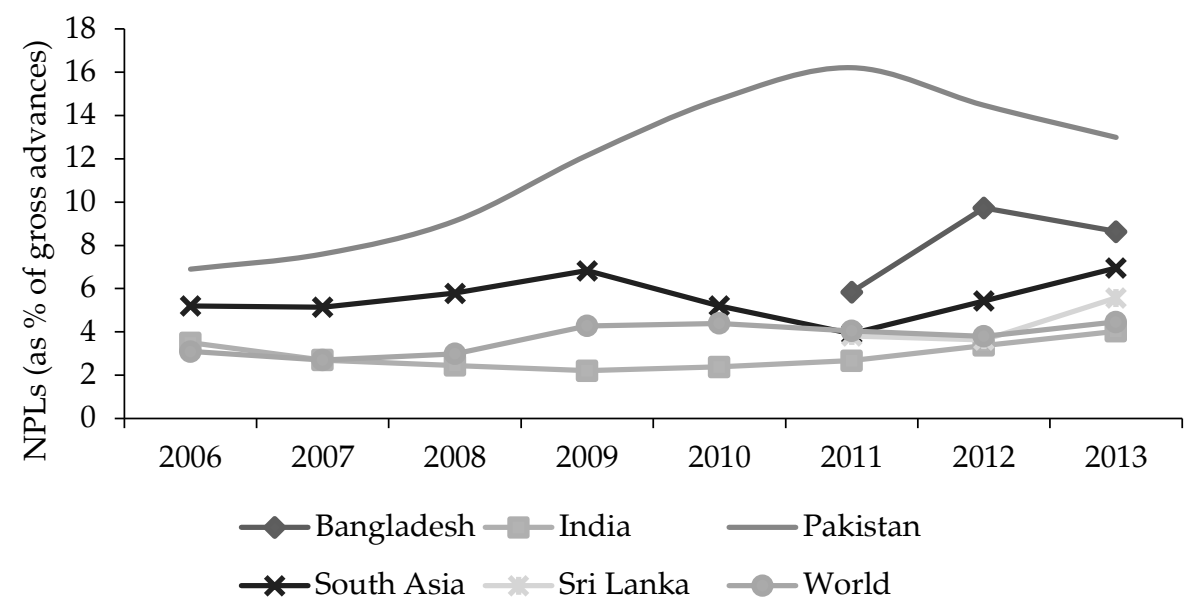

Source: Author's calculations based on data from the World Bank.

Figure 2: NPLs as a percentage of gross advances, by bank type

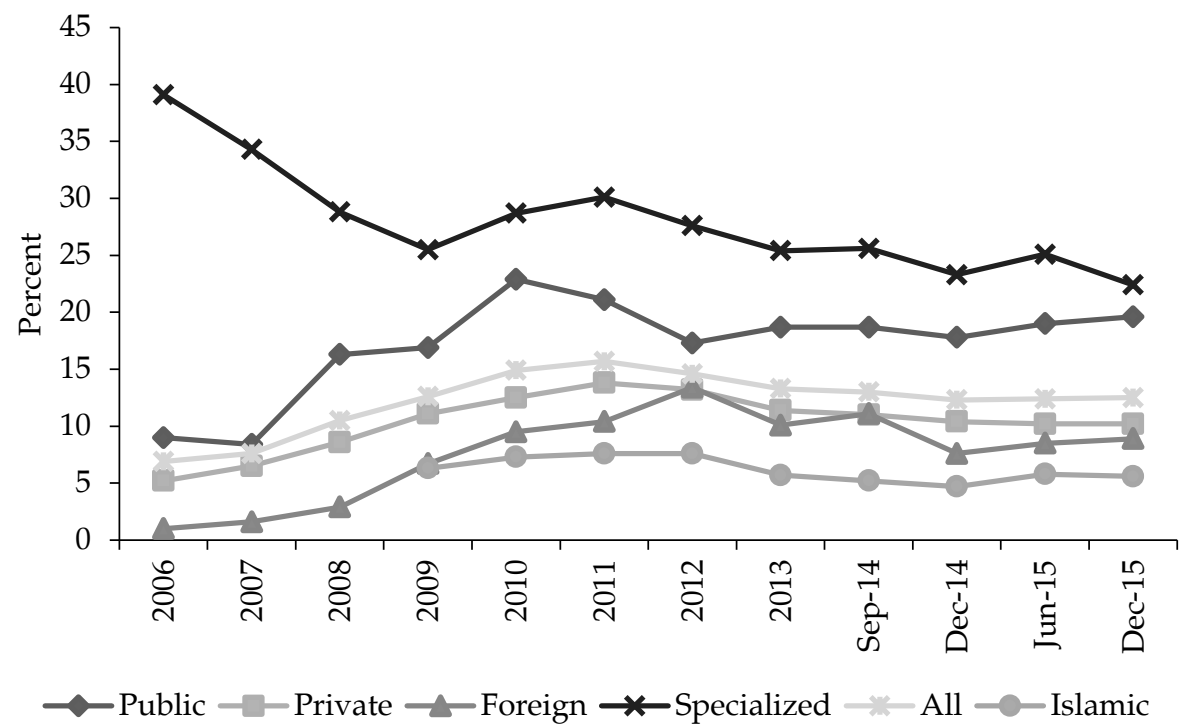

Source: Author's calculations based on data from the State Bank of Pakistan. 
Table 1: Distribution of NPLs, by finance segment, 2014

\begin{tabular}{lcccc}
\hline & \multicolumn{2}{c}{ Gross advances } & \multicolumn{2}{c}{ NPLs } \\
\cline { 2 - 5 } Segment & PRs billion & \% Share & PRs billion & \% Share \\
\hline Corporate & $3,060.2$ & 65.6 & 415.8 & 69.9 \\
SME & 264.5 & 5.7 & 89.7 & 15.1 \\
Agriculture & 245.6 & 5.3 & 36.4 & 6.1 \\
Consumer & 288.2 & 6.2 & 35.8 & 6.0 \\
Commodity & 570.8 & 12.2 & 4.6 & 0.8 \\
Other & 145.9 & 3.1 & 11.6 & 2.0 \\
Total & $4,661.8$ & 100.0 & 595.3 & 100.0 \\
\hline
\end{tabular}

Source: Author's calculations based on data from the State Bank of Pakistan.

Table 2: Distribution of bank credit, by area and segment, June 2015

\begin{tabular}{lrrr}
\hline Segment & Rural & Urban & Total \\
\hline Trust & $0.6 \%$ & $99.4 \%$ & $100.0 \%$ \\
Other & $5.0 \%$ & $95.0 \%$ & $100.0 \%$ \\
NBFC & $0.0 \%$ & $100.0 \%$ & $100.0 \%$ \\
Personal & $10.8 \%$ & $89.2 \%$ & $100.0 \%$ \\
NFPSE & $0.0 \%$ & $100.0 \%$ & $100.0 \%$ \\
Government & $0.0 \%$ & $100.0 \%$ & $100.0 \%$ \\
Private sector & $5.6 \%$ & $94.4 \%$ & $100.0 \%$ \\
Foreign & $0.0 \%$ & $0.0 \%$ & $0.0 \%$ \\
Total & $4.6 \%$ & $95.4 \%$ & $100.0 \%$ \\
\hline
\end{tabular}

Note: NBFC = nonbanking financial company, NFPSE = nonfinancial public sector enterprise. Source: Author's calculations based on data from the State Bank of Pakistan.

Motivated by the negative or very low real interest rate (RIR), which has never exceeded 4 percent, the nonfinancial corporate sector has borrowed on a large scale, significantly raising its debt-equity ratio (DER) and financial burden during the period 2006-10. This borrowing was used to expand the asset base - primarily noncurrent assets such as machinery and equipment - and to invest in speculative or nonproductive assets such as real estate (see Figure A1 in the Appendix). ${ }^{1}$

However, several factors have led to a sharp decline in asset turnover (corporate asset utilization), especially during 2006-10 (Figures 3a-h). These include severe energy shortfalls (Pakistan having been unable to expand its capacity to generate enough electricity and gas), expansions in the asset base,

\footnotetext{
${ }^{1}$ There is evidence that some cash-rich companies or groups of companies were even able to develop housing societies during this period.
} 
the global financial crisis, an adverse local macroeconomic environment, and poor law and order. ${ }^{2}$

Figure 3: NPLs and selected corporate (nonfinancial) sector and macroeconomic indicators

3a. NPLGA (NPL as a percentage of gross assets)

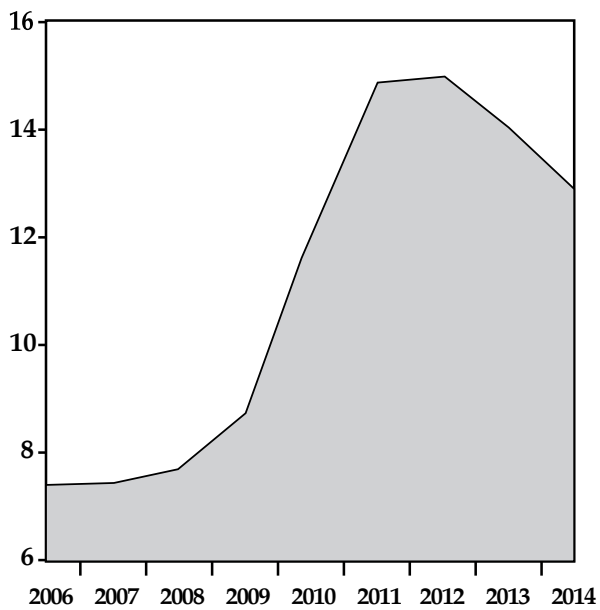

3c. DER (Debt equity ratio)

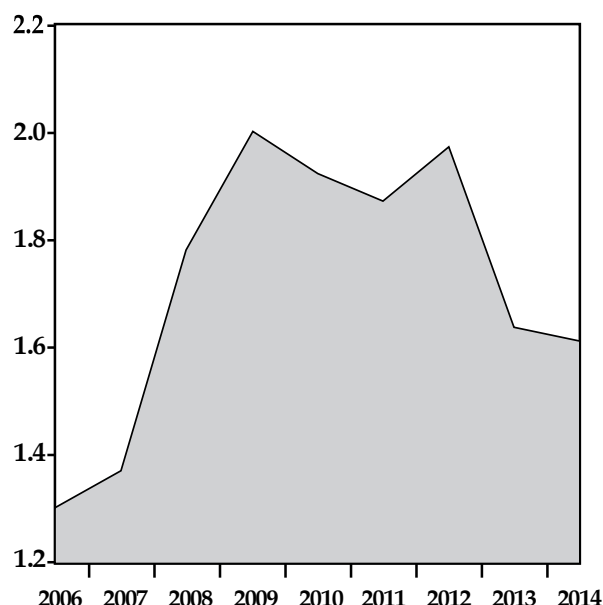

3b. RIR (Real interest rate)

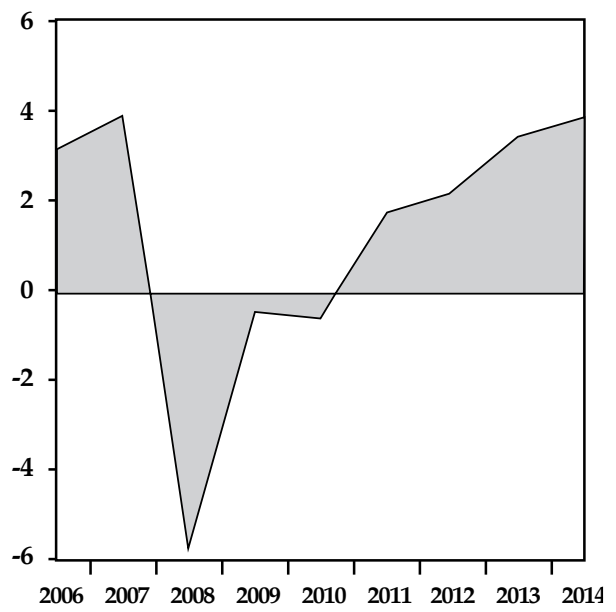

3d. FBCS (Corporate sector financial cost as a proportion of total sales)

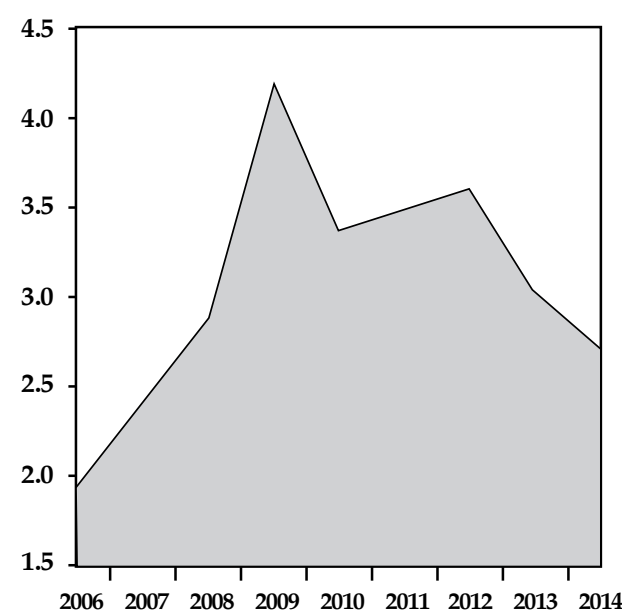

${ }^{2}$ Asset turnover ratio $=$ corporate sector sales $/$ total assets of corporate sector. 
3e. ATCS (Total sales of the corporate sector as a ratio of total assets)
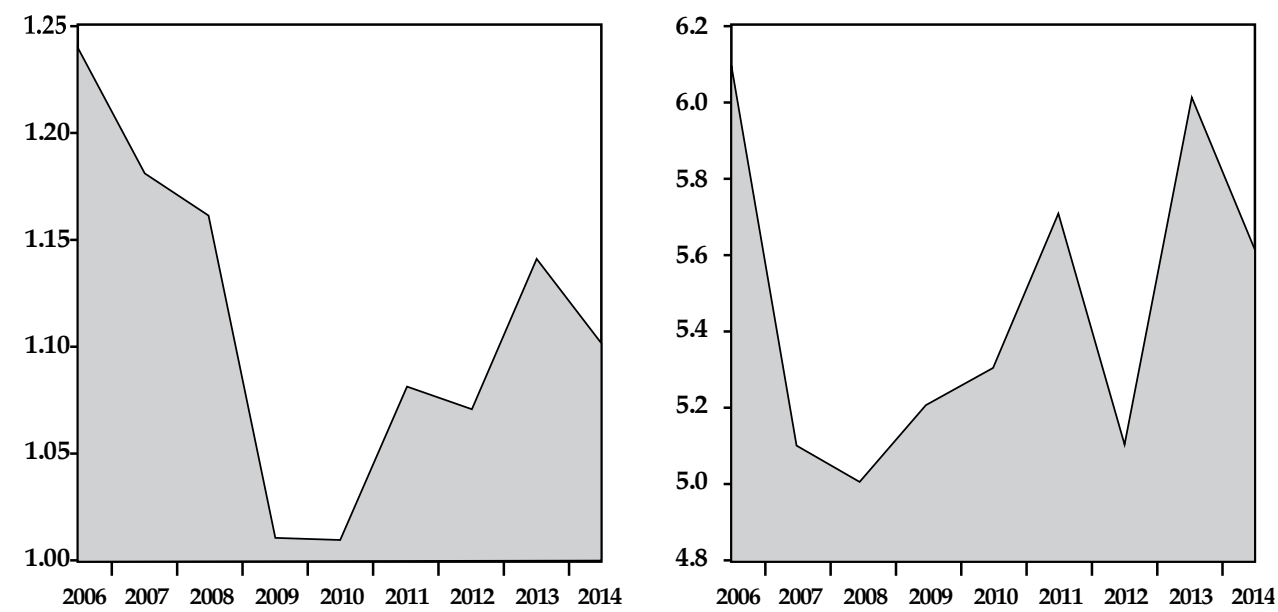

3g. INF (Average inflation rate) 3h. GDPG (GDP growth)
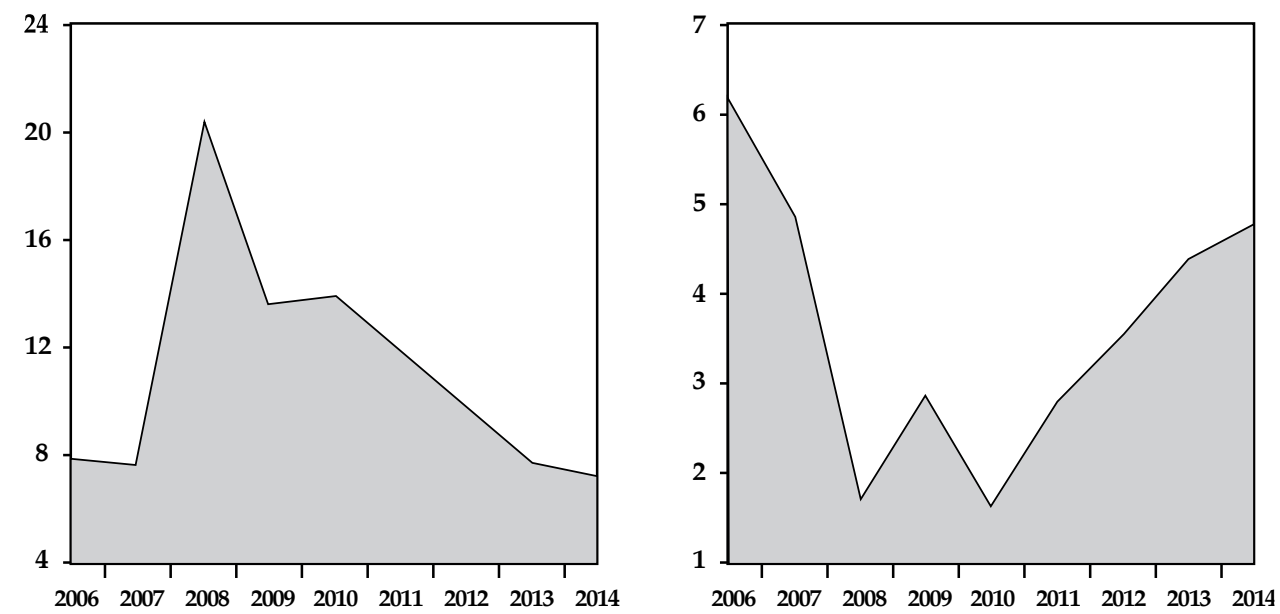

Source: Author's calculations based on data from the State Bank of Pakistan and Ministry of Finance, Government of Pakistan.

The corporate sector's noncurrent and total assets increased at a cumulative growth rate of 23.2 and 19.0 percent, respectively, while sales grew by only 13.0 percent during this period (Table 3 ). Greater financial leverage in terms of a larger financial burden and poor asset utilization has caused average bank asset quality to deteriorate, resulting in a sharp rise in NPLs, especially during 2006-10. Figure 4 shows that textiles, cement, electronics, automobiles and shoes/leather garments account for the highest NPLs. The incidence of loan defaulting in cement and automobiles - despite extensive 
construction activity and high demand for vehicles - is indicative of the moral hazard resulting from weak law enforcement in Pakistan. ${ }^{3}$

Table 3: Cumulative growth of various indicators

\begin{tabular}{lccc}
\hline Indicator & $\mathbf{2 0 0 6}-\mathbf{1 0}$ & $\mathbf{2 0 1 1 - 1 4}$ & $\mathbf{2 0 0 6 - 1 4}$ \\
\hline Sales & $13.0 \%$ & $10.2 \%$ & $12.9 \%$ \\
Fixed assets & $23.2 \%$ & $9.9 \%$ & $16.1 \%$ \\
Current assets & $14.1 \%$ & $8.5 \%$ & $12.8 \%$ \\
Total assets & $19.0 \%$ & $9.3 \%$ & $14.5 \%$ \\
Asset turnover & $-5.0 \%$ & $0.8 \%$ & $-1.5 \%$ \\
Real GDP & $2.7 \%$ & $4.2 \%$ & $3.3 \%$ \\
\hline
\end{tabular}

Source: Author's calculations based on data from the State Bank of Pakistan.

\section{Figure 4: Infection ratio, by sector}

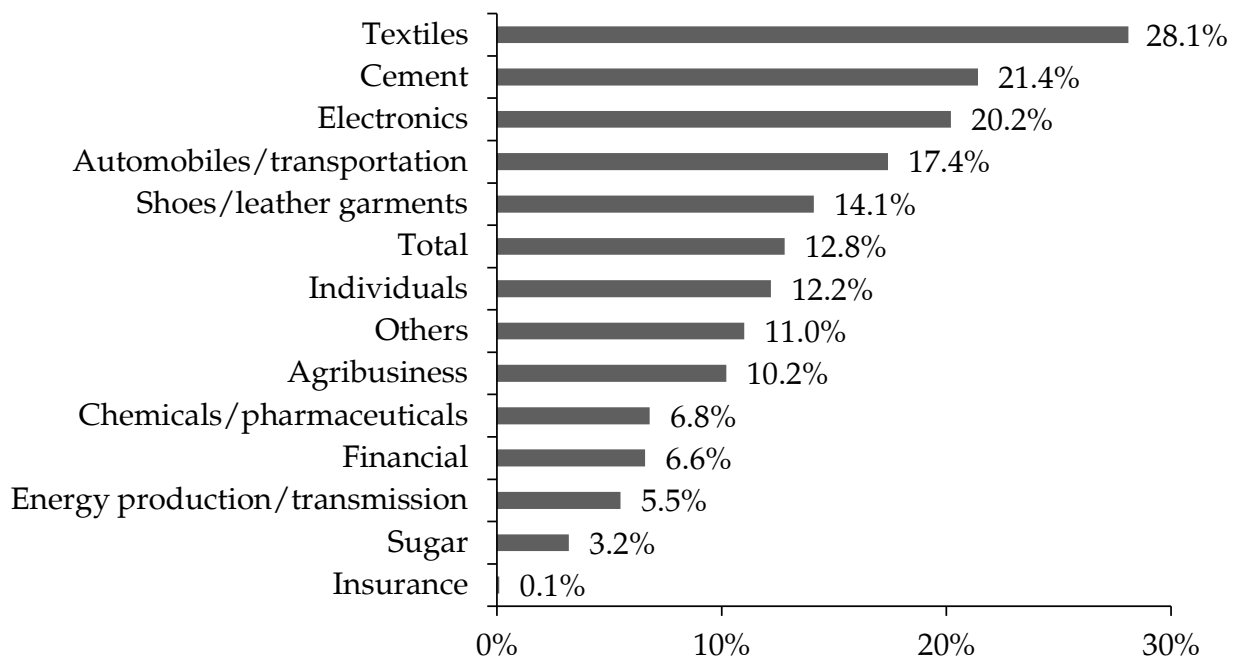

Source: Author's calculations based on data from the State Bank of Pakistan.

Figure 5 illustrates the gravity of the situation. For the Industrial Development Bank of Pakistan (IDBP) and HSBC Bank Middle East, NPLs account for 100 percent of gross advances. SME Bank and KASB Bank follow, with a corresponding share of 68 and 35 percent, respectively. The Bank of Punjab, NIB Bank and the Punjab Provincial Cooperative Bank account for 28,25 and 24 percent. Clearly, specialized and public banks in Pakistan tend to have the highest NPL levels, while Islamic banks have among the lowest.

\footnotetext{
${ }^{3}$ Customers in Pakistan must wait three to six months for delivery after booking.
} 
Figure 5: NPLs as a share of gross advances (individual banks), 2014

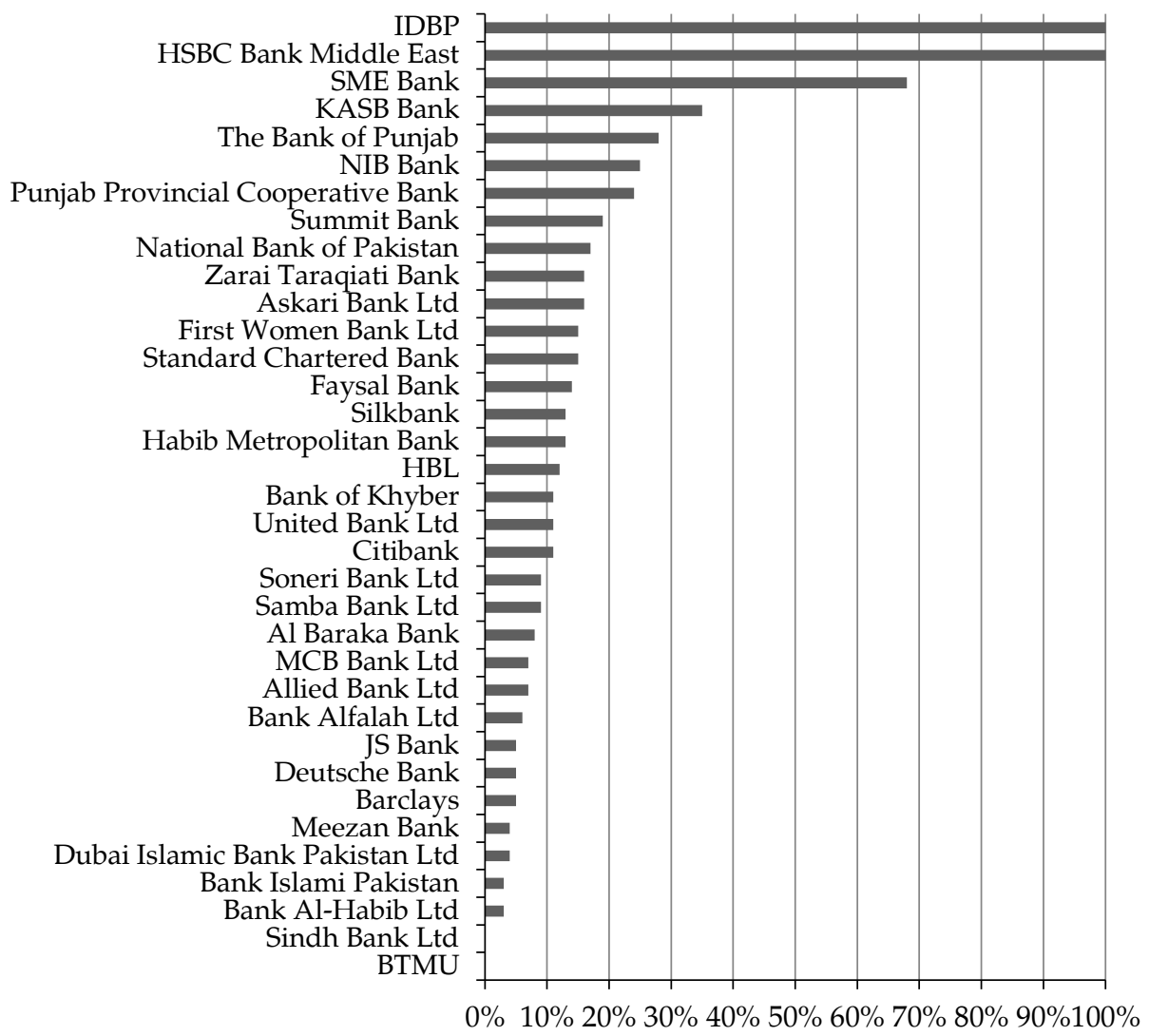

Source: Author's calculations based on data from the State Bank of Pakistan.

Larger banks appear to contribute more to the sector's total stock of NPLs than smaller banks (Figure 6). While Pakistan's macroeconomic recovery 2011 onward has improved the asset turnover of the corporate sector, this ratio is still far below its pre-2006 level. The NPL level has also fallen, but even this percentage is still excessive (see Figures 1-3).

A high NPL level can potentially deepen the severity and duration of a financial crisis and complicate macroeconomic management (Woo, 2000). It can also shatter investors' confidence in the banking system (Adhikary, 2006) and prevent economic recovery by cutting into profit margins and, therefore, the capital base for further lending (Bernanke \& Lown, 1991). Combined with weak law enforcement, this is likely to drive out bona fide borrowers through a contagious financial malaise - 'bad' borrowers will have a negative impact on 'good' borrowers by inducing the latter to prolong their payments (Adhikary, 2006). 
Figure 6: NPLs as a share of total NPLs (individual banks), 2014

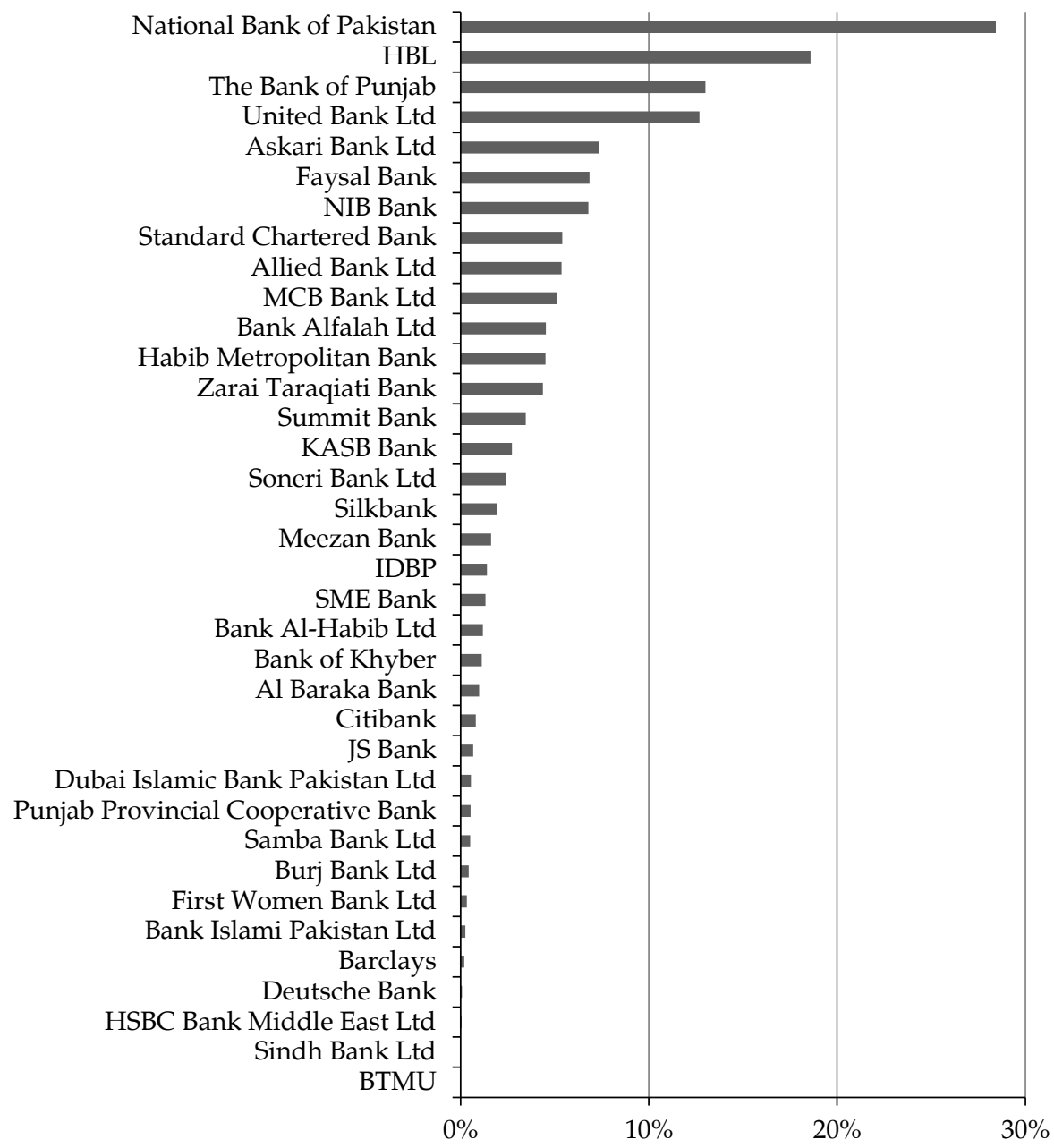

Source: Author's calculations based on data from the State Bank of Pakistan.

Given that a bank's primary assets are its loans, it is important to evaluate asset quality to determine the financial health and efficiency of the banking sector (Islam, Karim \& Islam, 2014). De Bock and Demyanets (2012) find that economic growth slows down and exchange rates depreciate in emerging markets characterized by very high NPL levels. This context explains the need to explore the key determinants of NPLs in Pakistan, a better understanding of which would help policymakers, corporate managers and regulators identify the sector's vulnerable points and formulate policies to control the high level of NPLs in the country. 
In identifying the determinants of NPLs, the literature tends to neglect the role of aggregate corporate sector indicators and the diversification of bank activities. The study seeks to address this gap, using panel least squares and fixed effects (FE) to examine a sample of 40 banks in Pakistan for the period 2006-14. We find that bank-specific variables and corporate sector indicators explain the variation in NPLs better than the state of the macroeconomic environment.

The study's findings suggest that the concentration of the credit market, the lending rate, the cost of living, stock prices, bank size, public sector ownership, specialized banking, the DER and financial burden have a positive and significant impact on NPLs. Factors that significantly reduce NPLs include the diversification of bank activities, the scale of loan appraisal and monitoring systems, Islamic banking, corporate asset turnover and a favorable macroeconomic environment. Foreign banking and nominal exchange rate movements have an insignificant impact, given that bank lending to foreign borrowers is nil.

The remaining paper is organized as follows. Section 2 provides a comprehensive review of the literature on bank asset quality and its determinants. Sections 3-5 describe the study's dataset, methodology and research design. Section 6 presents the study's findings and Section 7 concludes the study with a set of policy implications.

\section{A Review of the Literature}

Çifter (2015) uses the generalized method of moments and instrumental variable approach to examine the short- and long-run effects of bank concentration on NPLs across 10 Central and Eastern European countries. The study employs a fully modified ordinary least squares (OLS) model and finds that bank concentration has an insignificant impact on NPLs both in the short run and long run. However, the individual fully modified OLS results reveal that bank concentration reduces NPLs in Estonia, Latvia and Slovakia, and increases NPLs in Bulgaria, Croatia, Lithuania, Poland and Slovenia in the long run.

Klein (2013) observes that macroeconomic conditions have greater explanatory power than bank-specific factors, with a strong feedback effect from NPLs to the real economy in Central, Eastern and Southeastern Europe over the period 1998-2011. The study suggests that unemployment, inflation and the exchange rate have a positive and significant effect on NPLs. Among bank-level variables, the capital ratio and returns on equity have a negative 
impact, while financial leverage has a positive impact on NPLs. Looking at consumer, business and mortgage loans separately, Louzis, Vouldis and Metaxas (2012) find that NPLs in Greece are determined chiefly by macrofundamentals (GDP, the unemployment rate and interest rates) and management quality.

In a cross-country study of 75 countries, Beck, Jakubik and Piloiu (2015) identify GDP growth, the exchange rate, the lending interest rate and stock prices as the key macroeconomic determinants of NPLs. GDP growth is indicative of more employment opportunities and boosts economic activity, which in turn directly influences the ability of borrowers to repay their debt, thus reducing the volume of NPLs. Higher stock prices tend to lower housing prices, which reduces the quality of housing loans. Higher lending interest rates raise the cost of borrowing and, therefore, the likelihood of default or NPLs.

Using an FE model for a panel dataset, Khemraj and Pasha (2009) note that the real effective exchange rate, bank size, rapid credit growth and higher interest rates have a positive effect on NPLs. Boudriga, Taktak and Jellouli (2010) conclude that higher bank capitalization and prudent provisioning policy, private ownership, foreign participation and bank concentration reduce the volume of NPLs. Siddiqui, Malik and Shah (2012) find that interest rates are significantly - but not solely - responsible for NPLs in Pakistan. Based on a sample of Spanish banks, Salas and Saurina (2002) find that NPLs are influenced by individual bank-level variables such as bank size, the net interest margin, the capital ratio and market power in addition to real GDP growth. Beck, Demirgüç-Kunt and Merrouche (2013) suggest that Islamic bank stocks perform better than conventional stocks, based on their asset quality and capitalization.

Using bank-level data for a sample of 26 commercial banks over the period 2001-10, Hussain (2012) finds that previous NPLs, credit growth, interest margins, foreign and public sector bank ownership, corporate gearing, currency depreciation and the real cost of debt have a positive and significant impact on the volume of NPLs. Bank size and profitability, industrial growth and profitability, GDP growth and per capita income have a negative impact in this case. Finally, Glen and Mondragón-Vélez (2011) identify real GDP growth, private sector leverage and insufficient capitalization within the banking system as the key determinants of loan loss provision in 22 developing economies during 1996-2008. 
Private sector enterprises borrow to expand their asset base. Debt repayment depends on a firm's ability to utilize these assets to increase its general sales or revenue (asset turnover) and reduce its financial burden (financial expenses as a percentage of sales) consequent to increased financial leverage. Despite the importance of asset turnover and financial burden as indicators of the corporate sector, they have received little attention in the literature. Both indicators are especially relevant in Pakistan's case, where 65.6 percent of total advances are channeled to the corporate sector alone, which accounts for almost 70 percent of the total volume of NPLs in the banking industry.

Unlike most other studies, this study controls for four types of banks (see below). It builds on Hussain (2012) and includes the following three categories of NPL determinants:

- Bank or banking industry-specific factors: credit market concentration (size and growth of loan portfolios), the diversification of bank activities, the lending rate of interest, bank size, bank capitalization, the size of the loan appraisal and monitoring system, bank ownership and bank type (with dummy variables representing Islamic versus conventional, public versus private, specialized versus nonspecialized and local versus foreign banks).

- Macroeconomic indicators: GDP growth, inflation, the exchange rate, stock prices, the real cost of debt (the RIR) and per capita income.

- Corporate sector indicators: capital structure or financial leverage, financial burden and asset utilization.

\section{Datasets and Sample}

We use bank-level data for the period 2006-14, drawing on the State Bank of Pakistan's balance sheet analyses of the financial sector (for 2009/10 and 2010-14) and periodically published banking statistics. The study's nonfinancial corporate sector data was obtained from the balance sheet analyses of nonfinancial companies listed on the Karachi Stock Exchange (2009/10 and 2010-14). The data on macroeconomic indicators is from the Pakistan Economic Survey and World Bank database.

The sample comprises all 40 banks operating in Pakistan, including private, public, Islamic, conventional, local, foreign, specialized and nonspecialized banks. The study covers the period 2006-14 for two reasons: (i) the low RIR regime that started in 2005 motivated firms to borrow large 
amounts, which increased their financial leverage; and (ii) asset utilization began to decline in 2006, largely due to the energy crisis and constant power outages, security concerns on account of increased militancy and the overall adverse macroeconomic environment.

\section{Construction of Variables}

This section describes each of the variables used.

\subsection{Dependent Variable}

The NPL rate is the dependent variable. To enable comparison across banks, countries and regional aggregates, we use the ratio of NPLs to gross advances as a proxy for NPLs:

$$
N P L G A_{i t}=\frac{N P L_{i t}}{G A_{i t}} * 100
$$

where NPLGA $A_{i t}$ represents NPLs as a percentage of gross advances, $i$ denotes the cross-section (bank) and $t$ denotes time. $N P L_{i t}$ is the volume of NPLs for bank $i$ at the end of period $t$ and $G A_{i t}$ denotes the gross advances of bank $i$ at the end of period $t$.

\subsection{Independent Variables}

Bank concentration in the credit market. We use gross advances as a share of total assets as a proxy for the bank's concentration in the credit market:

$$
C C M_{i t}=\frac{G A_{i t}}{T A_{i t}}
$$

$C C M_{i t}$ captures both the relative size and growth of the bank's loan portfolio. An increase in $C C M_{i t}$ over time is indicative of an increase in the size and growth of the lending portfolio.

Banks that lend to low-quality borrowers face higher NPL levels during periods of low interest or credit booms because their capacity to process loan applications is constrained (Berger \& Udell, 2004; Fernández de Lis, Pagés \& Saurina, 2001). Keeton (1999) and Kwan and Eisenbeis (1997) find that rapid credit growth leads to larger loan losses because banks that pursue credit growth (especially during the expansion phase of the business cycle) tend to lower their standards of loan appraisal. This, in turn, raises NPLs. 
During episodes of low credit growth or a recession, NPL levels rise (Eisenbeis, 1997) because borrowers draw down their lines of equity and credit in addition to the decline in their business, which compels them to default. We expect $C C M_{i t}$ to have a positive coefficient: the larger the lending portfolio or the higher its growth rate, the more likely the incidence of NPLs (although the coefficient can also be negative).

An alternative measure is the simple growth rate of the lending portfolio $\left(C G_{i t}\right)$ :

$$
C G_{i t}=\frac{\Delta G A_{i t}}{G A_{i t}} * 100
$$

where $\Delta G A_{i t}$ denotes the change in gross advances and $G A_{i t}$ the gross advances of bank $i$ in period $t$.

Bank lending interest rate. The average lending interest rate charged by the bank on good or collectible advances is:

$$
L I R_{i t}=\frac{I R_{i t}}{A N_{i t}} * 100
$$

where $I R_{i t}$ is the interest revenue earned and $A N_{i t}$ denotes good or collectible advances or loans. We use net advances instead of gross advances in equation (2) because banks earn interest revenue on collectible loans. Banks that earn higher interest revenue on good loans are more vulnerable to bad debts. Equally, NPLs increase with the interest rate because it raises the debt servicing cost of borrowers with floating rate contracts (Espinoza \& Prasad, 2010; Kauko, 2012; Beck et al., 2015).

Here, the average lending interest rate (charged by an individual bank on its collectible loans) is different from the policy rate because the short-term policy rates set by the central bank are not transmitted fully to the lending interest rates (Beck et al., 2015).

Diversification of bank activities. Higher noninterest revenue is indicative of greater diversification in terms of bank activities other than borrowing and lending and is measured as follows:

$$
D I V_{i t}=\frac{N I R_{i t}}{T A_{i t}} * 100
$$


where $N I R_{i t}$ represents the bank's noninterest revenue and $T A_{i t}$ its total assets. Greater diversification is likely to reduce the level of NPLs, but is rarely included as a determinant in the literature.

Size of loan appraisal and monitoring system. While administrative expenses are often used as a proxy for cost efficiency (see Berger \& DeYoung, 1997; Podpiera \& Weill, 2008), this study broadens the indicator by looking at the level and growth of a bank's administrative expenses to measure the size of its loan appraisal and monitoring system:

$$
S A M S_{i t}=\log \left(A E_{i t}\right)
$$

A larger loan appraisal and monitoring system is indicative of the bank's capacity for appraising and monitoring loan applications and is, therefore, likely to reduce the level of NPLs.

Bank capitalization. Bank capitalization is the ratio of stockholders' equity to the bank's total assets:

$$
C R_{i t}=\frac{S E_{i t}}{T A_{i t}}
$$

where $S E_{i t}$ denotes shareholders' equity and $T A_{i t}$ the bank's total assets. Higher bank capitalization reduces NPLs as financially strong banks are less likely to invest in risky projects (Boudriga et al., 2010; Louzis et al., 2012; Klein, 2013).

Bank size. Bank size is measured as a bank's total assets in proportion to the banking industry's total assets:

$$
B S_{i t}=\frac{T A_{i t}}{\sum_{i=1}^{n} T A_{i t}} * 100
$$

where $T A_{i t}$ represents the total assets of bank $\underline{i}$ in period $t$ while $\sum_{i=1}^{n} T A_{i t}$ is the sum of total assets owned by $n$ banks in period $t$.

Bank size is also indicative of a bank's market power, which may be associated with higher NPLs: larger banks are more likely to be interested in cornering a larger share of the market by investing in risky projects with a higher incidence of NPLs (Khemraj \& Pasha, 2009). That said, larger banks are also likely to have better loan appraisal and monitoring systems in place, which would reduce their NPLs (Louzis et al., 2012; Salas \& Saurina, 2002). 
Bank type. We use dummy variables to control for NPLs across the four types of banks: D1 = 1 for public banks and 0 otherwise, D2 = 1 for Islamic banks and 0 otherwise, D3 = 1 for foreign banks and 0 otherwise, and D4 = 1 for specialized banks and 0 otherwise.

Corporate asset utilization. The asset turnover of the corporate sector is a proxy for corporate asset utilization, calculated as follows:

$$
A T C S_{t}=\frac{S C S_{t}}{T A C S_{t}}
$$

where $S C S_{t}$ denotes the total sales of the corporate sector and $\operatorname{TACS}_{t}$ its total assets. Higher corporate asset utilization implies that the sector's ability to repay its loans is greater, which reduces the incidence of NPLs.

Corporate financial leverage. While there are different measures of financial leverage, including the gearing ratio, equity multiplier and debt ratio, we use the most common measure, the DER, as a proxy for financial leverage:

$$
D E R_{t}=\frac{T L_{t}}{S E_{t}}
$$

where $T L_{t}$ and $S E_{t}$ represent the total liabilities and total stockholders' equity of the corporate sector. A higher DER is indicative of greater risk of default, which is likely to raise the NPL level.

Corporate financial burden. Financing costs, including interest expenses as a percentage of sales, are used as a proxy for the corporate sector's financial burden:

$$
F B C S_{t}=\frac{F C C S_{t}}{S C S_{t}} * 100
$$

where $F C C S_{t}$ and $S C S_{t}$ denote the sector's financing costs and total sales, respectively. A higher corporate financial burden increases the likelihood of default and the level of NPLs.

The financial burden can also be captured using the lending RIR or cost of borrowing as follows:

$$
R I R_{t}=A I R_{t}-I N F_{t}
$$


where $A I R_{t}$ and $I N F_{t}$ are the average lending interest rate and inflation rate, respectively. A higher RIR (the real cost of debt servicing) is likely to raise the probability of default and the NPL level.

Inflation. We use the consumer price index as a measure of inflation, which affects the ability of both individuals and institutions to repay their debts. Borrowers tend to benefit from a fixed rather than varying inflation rate, which implies that higher inflation can increase the NPL level (Klein, 2013). However, it may also improve loan repayment by making loans cheaper to repay (Anastasiou, Lourie \& Tsionas, 2016), thus reducing the level of NPLs.

Macroeconomic environment. Real GDP growth, measured by $\log$ $\left(R G D P_{t}\right)$, and per capita income $\left(P C I_{t}\right)$ are tested separately in alternative specifications to capture the effect of the macroeconomic environment on NPLs. The unemployment rate can also be used for this purpose (see Klein, 2013). An adverse macroeconomic environment is likely to raise NPLs and vice versa (Klein, 2013; Messai \& Jouini, 2013; Beck et al., 2015; Anastasiou et al., 2016).

Nominal exchange rate. Movements in the nominal exchange rate $N E R_{t}$ capture the impact of global changes on NPLs. Depending on a country's foreign assets and liabilities, the nominal exchange rate can affect NPLs either positively or negatively (Klein, 2013; Beck et al., 2015). Exchange rates can also influence NPLs through trade finance (Beck et al., 2015).

Stock prices. The KSE-100 index $\left(K S E H_{t}\right)$ is used to measure stock price movements. Since stock prices are correlated with housing (and other asset) prices, they have an indirect impact on the value of collateral and, therefore, on the quality of loans (Beck et al., 2015).

Proportion of lending to the textiles sector. We control for the impact of the largest share of lending by using the percentage of bank lending to the textiles sector $\left(L P T S_{t}\right)$. This is likely to have a positive effect on potential defaults, given the sector's political influence.

Global financial crisis. The impact of the global financial crisis on NPLs is captured by a dummy variable (D5), where D5 = 1 for 2009 and 0 otherwise.

Share of bank lending to the corporate sector. We control for the impact of the share of bank lending to the corporate sector by introducing a dummy 
variable (D6), where D6 = 1 if the share of bank lending to this sector is 50 percent or higher in a given year and 0 otherwise.

\section{Methodology}

This study combines cross-section and time series data and uses panel least squares and FE regression models of the following standard forms, respectively:

$$
\begin{aligned}
& N P L G A_{i t}=\beta_{0}+\beta_{1} X_{i t}+\beta_{2} Y_{t}+\beta_{3} Z_{t}+\alpha_{i}+\mu_{t}+\varepsilon_{i t} \\
& N P L G A_{i t}=\beta_{0}+\beta_{1} X_{i t}+\varepsilon_{i t}
\end{aligned}
$$

where NPLGA $A_{i t}$ denotes NPLs as a percentage of gross advances and $i$ and $t$ specify the cross-section and time, respectively. $\beta_{0}, \beta_{1}, \beta_{2}$ and $\beta_{3}$ are unknown constants. $X_{i t}$ is a set of bank-specific explanatory variables that vary across banks and time. $Y_{t}$ and $Z_{t}$ are vectors of macroeconomic and nonfinancial corporate sector-specific variables that vary over time only. $\alpha_{i}$ and $\mu_{t}$ denote cross-section and time effects (random or fixed), respectively, while $\varepsilon_{i t}$ is the error term.

The error term and its relationship with the explanatory variables in both models is very important. The use of OLS in equation (1) above assumes the absence of unobservable firm- and time-specific factors, while the FE model in equation (2) assumes that $\varepsilon_{i t}$ varies nonstochastically over $i$ or $t$. This makes the model analogous to a dummy variable model in one dimension. The FE model also assumes that cross-sections have unique attributes that do not vary over time and are not a result of random variation. The model thus provides consistent estimates regardless of the correlation mentioned above.

\section{Results and Discussion}

Tables 4 and 5 present the study's descriptive statistics and a matrix of correlation coefficients, respectively. While there is evidence of very low correlation between the bank-specific variables and aggregate indicators of the nonfinancial corporate sector, there is relatively high correlation among the macroeconomic indicators and no evidence of perfect multicollinearity.

Table 6 gives the results of the cross-section and period FE models. Table 7 reports the results of the redundant FE tests (joint significance). The use of FE is justified because the cross-section and period effects are significant. Tables 8-10 present the regression results of the panel least 
squares model (for all banks and excluding specialized banks with an NPL level of 100 percent) and FE model.

Table 4: Descriptive statistics

\begin{tabular}{lllllllllr}
\hline & NPLGA & CCM & \multicolumn{1}{c}{ LIR } & \multicolumn{1}{c}{ DIV } & \multicolumn{1}{c}{ SAMS } & CR & BS & D1 & D2 \\
\hline Mean & 0.17 & 0.52 & 0.35 & 0.00 & 14.62 & 0.06 & 0.03 & 0.25 & 0.13 \\
Median & 0.10 & 0.51 & 0.18 & 0.01 & 14.73 & 0.10 & 0.01 & 0.00 & 0.00 \\
Max. & 1.00 & 1.65 & 17.87 & 0.09 & 17.60 & 5.57 & 0.16 & 1.00 & 1.00 \\
Min. & 0.00 & 0.01 & 0.00 & -0.22 & 6.91 & -7.21 & 0.00 & 0.00 & 0.00 \\
SD & 0.21 & 0.22 & 1.40 & 0.03 & 1.56 & 1.00 & 0.04 & 0.43 & 0.34 \\
Skewness & 2.36 & 1.71 & 11.44 & -2.51 & -0.77 & -3.20 & 1.97 & 1.15 & 2.21 \\
Kurtosis & 8.68 & 8.98 & 140.01 & 17.54 & 4.38 & 32.00 & 6.42 & 2.33 & 5.88 \\
Prob. & 0.0000 & 0.0000 & 0.0000 & 0.0000 & 0.0000 & 0.0000 & 0.0000 & 0.0000 & 0.0000 \\
Obs. & 339 & 340 & 340 & 340 & 340 & 340 & 340 & 340 & 340 \\
\hline
\end{tabular}

Source: Author's calculations based on data from the State Bank of Pakistan. 


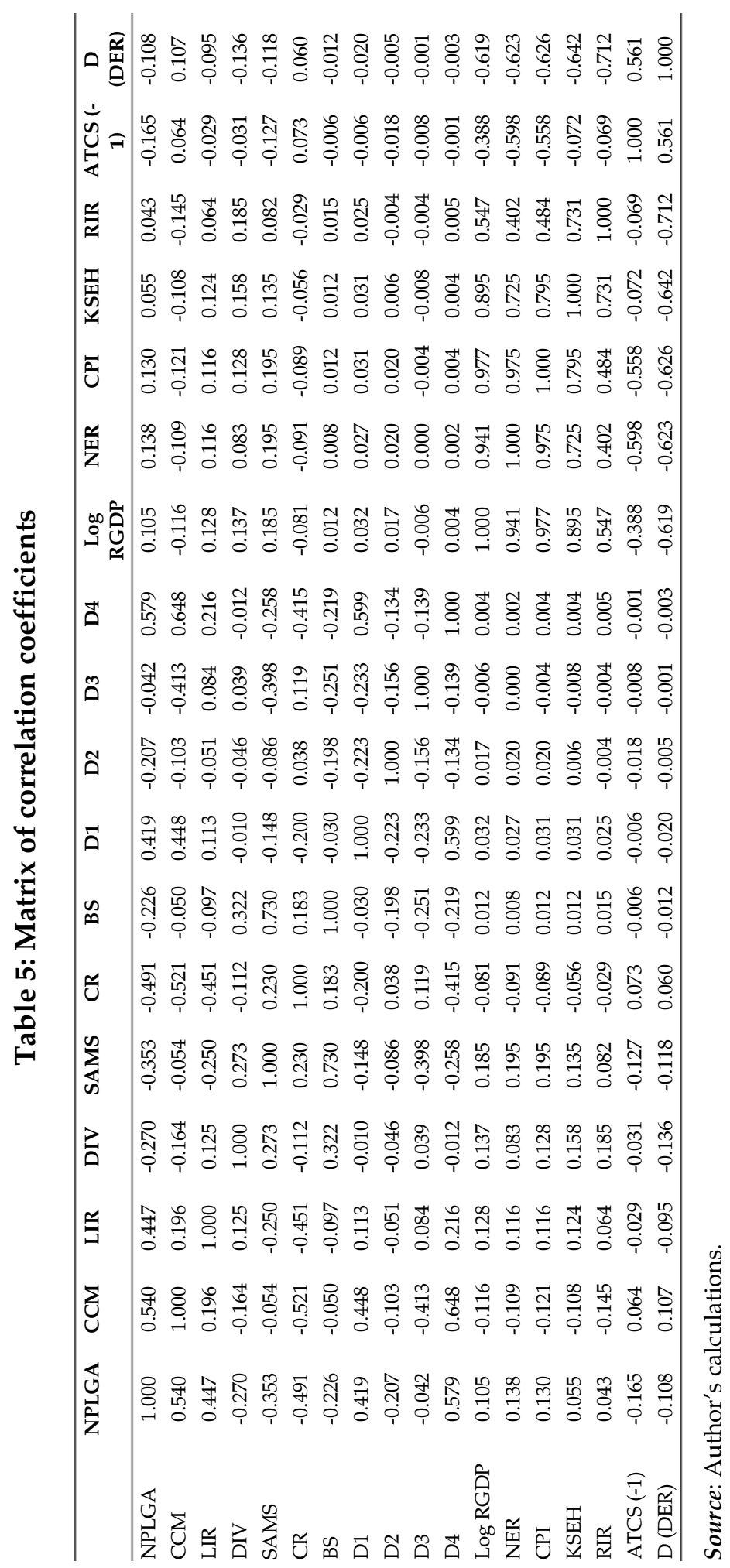


Table 6: Evidence of FE

\begin{tabular}{|c|c|c|c|c|c|}
\hline \multicolumn{3}{|c|}{ Cross-section FE } & \multicolumn{3}{|c|}{ Period FE } \\
\hline & CROSSID & Effect & & DATEID & Effect \\
\hline 1 & 1 & -0.1460 & 1 & $1 / 1 / 2007$ & -0.0660 \\
\hline 2 & 2 & 0.0041 & 2 & $1 / 1 / 2008$ & -0.0450 \\
\hline 3 & 3 & -0.0290 & 3 & $1 / 1 / 2009$ & -0.0150 \\
\hline 4 & 4 & -0.0240 & 4 & $1 / 1 / 2010$ & 0.0378 \\
\hline 5 & 5 & -0.1260 & 5 & $1 / 1 / 2011$ & 0.0250 \\
\hline 6 & 6 & -0.2460 & 6 & $1 / 1 / 2012$ & 0.0335 \\
\hline 7 & 7 & 0.0490 & 7 & $1 / 1 / 2013$ & 0.0166 \\
\hline 8 & 8 & 0.0340 & 8 & $1 / 1 / 2014$ & 0.0131 \\
\hline 9 & 9 & -0.0980 & & & \\
\hline 10 & 10 & -0.0430 & & & \\
\hline 11 & 11 & 0.0072 & & & \\
\hline 12 & 12 & -0.1290 & & & \\
\hline 13 & 13 & 0.0271 & & & \\
\hline 14 & 14 & 0.1509 & & & \\
\hline 15 & 15 & -0.0090 & & & \\
\hline 16 & 16 & -0.0880 & & & \\
\hline 17 & 17 & 0.0184 & & & \\
\hline 18 & 18 & 0.0801 & & & \\
\hline 19 & 19 & 0.0544 & & & \\
\hline 20 & 20 & 0.0889 & & & \\
\hline 21 & 21 & -0.0750 & & & \\
\hline 22 & 22 & 0.0028 & & & \\
\hline 23 & 23 & -0.0360 & & & \\
\hline 24 & 24 & 0.0810 & & & \\
\hline 25 & 25 & -0.0570 & & & \\
\hline 26 & 26 & 0.1246 & & & \\
\hline 27 & 27 & -0.1520 & & & \\
\hline 28 & 28 & 0.1816 & & & \\
\hline 29 & 29 & -0.0450 & & & \\
\hline 30 & 30 & 0.0975 & & & \\
\hline 31 & 31 & -0.1580 & & & \\
\hline 32 & 32 & 0.1250 & & & \\
\hline 33 & 33 & 0.0994 & & & \\
\hline 34 & 34 & 0.0628 & & & \\
\hline 35 & 35 & 0.2623 & & & \\
\hline 36 & 36 & 0.0856 & & & \\
\hline 37 & 37 & -0.1020 & & & \\
\hline 38 & 38 & -0.1430 & & & \\
\hline 39 & 39 & -0.1050 & & & \\
\hline 40 & 40 & -0.0450 & & & \\
\hline
\end{tabular}

Source: Author's calculations. 
Table 7: Redundant FE test results

\begin{tabular}{lrcc}
\hline Effects test & Statistic & df & Prob. \\
\hline Cross-section FE & 2.05 & $(39,245)$ & 0.0000 \\
Cross-section chi-square & 84.39 & 39 & 0.0000 \\
Period FE & 3.83 & $(7,245)$ & 0.0000 \\
Period chi-square & 31.08 & 7 & 0.0000 \\
Cross-section/period FE & 2.12 & $(46,245)$ & 0.0000 \\
Cross-section/period chi-square & 100.39 & 46 & 0.0000 \\
\hline
\end{tabular}

Source: Author's calculations.

Banks' concentration in the credit market (or credit growth) has a significant and positive coefficient. ${ }^{4}$ The positive coefficient is consistent with the findings of Berger and Udell (2004), Fernández de Lis et al. (2001), Keeton (1999) and Kwan and Eisenbeis (1997).

The lending interest rate has a positive, significant (at 1 percent across all specifications) impact on NPLs. The coefficient is stable and theoretically consistent with the findings of Espinoza and Prasad (2010), Kauko (2012) and Beck et al. (2015).

The diversification variable has a significant (at 1 percent across all specifications) and negative impact on NPLs. The sign of the coefficient is as expected.

Banks that offer their employees attractive remuneration (the growth of employee incentives) or spend more on loan appraisals are in a better position to control and monitor credit provision, which significantly reduces their NPLs (excluding specifications 9 and 10).

The negative and significant (at 5 percent) coefficient of the capitalization ratio signifies that financially strong, stable banks avoid risky lending and thus have relatively low NPL levels. This finding is consistent with Boudriga et al. (2010), Louzis et al. (2012) and Klein (2013).

Bank size has a positive and significant coefficient (at a 5 percent confidence level) in most specifications with a stable magnitude, excluding specifications 6-9. This finding is consistent with Khemraj and Pasha (2009), but contradicts Louzis et al. (2012) and Salas and Saurina (2002). The hypothesis that larger banks are more inclined to undertake risky lending holds, therefore, in Pakistan's case.

\footnotetext{
${ }^{4}$ At a 1 percent confidence level, excluding specifications 10 and 11 where it is significant at 5 percent.
} 


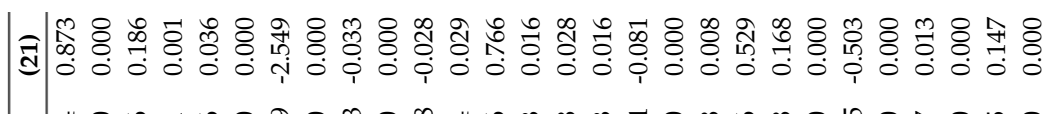

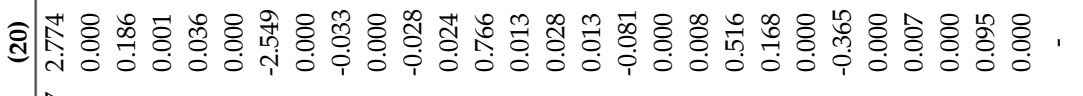

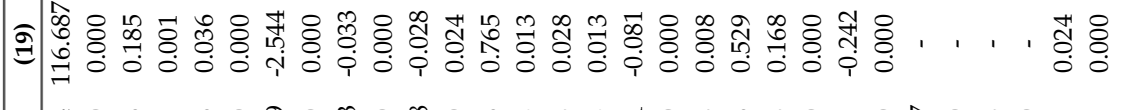

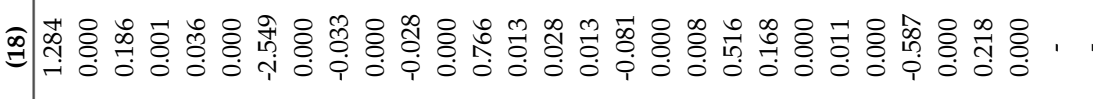

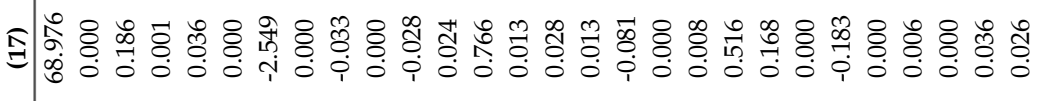

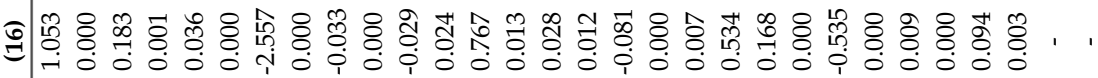

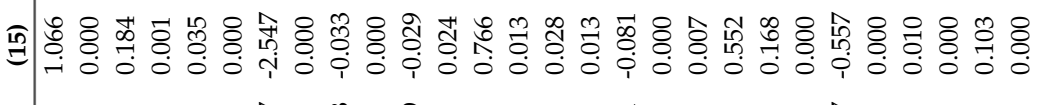

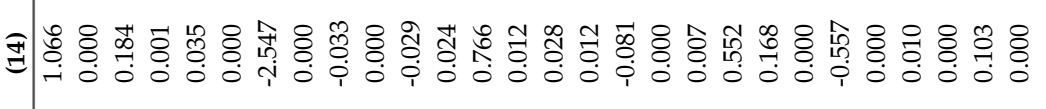

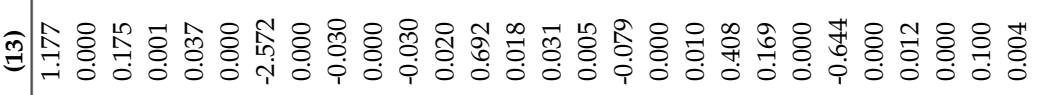

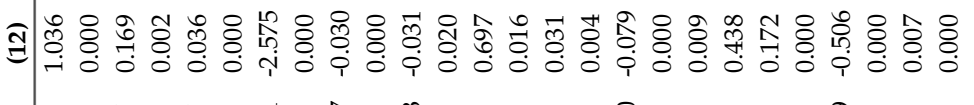

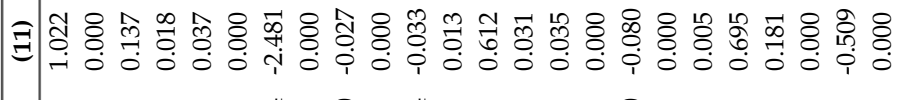
司 ๔

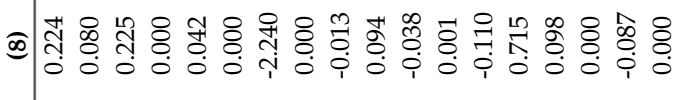
E ⿶凵人

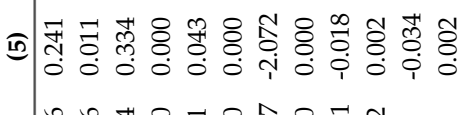

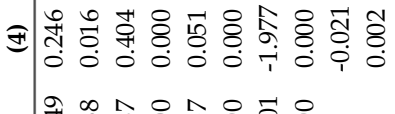

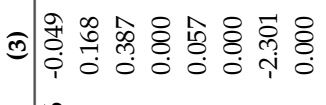
领

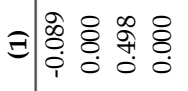

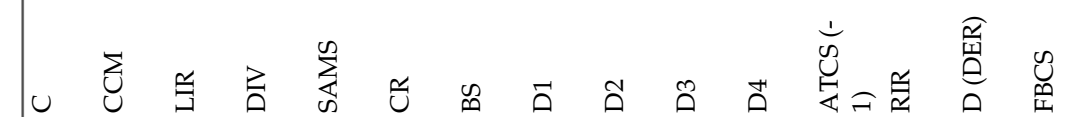




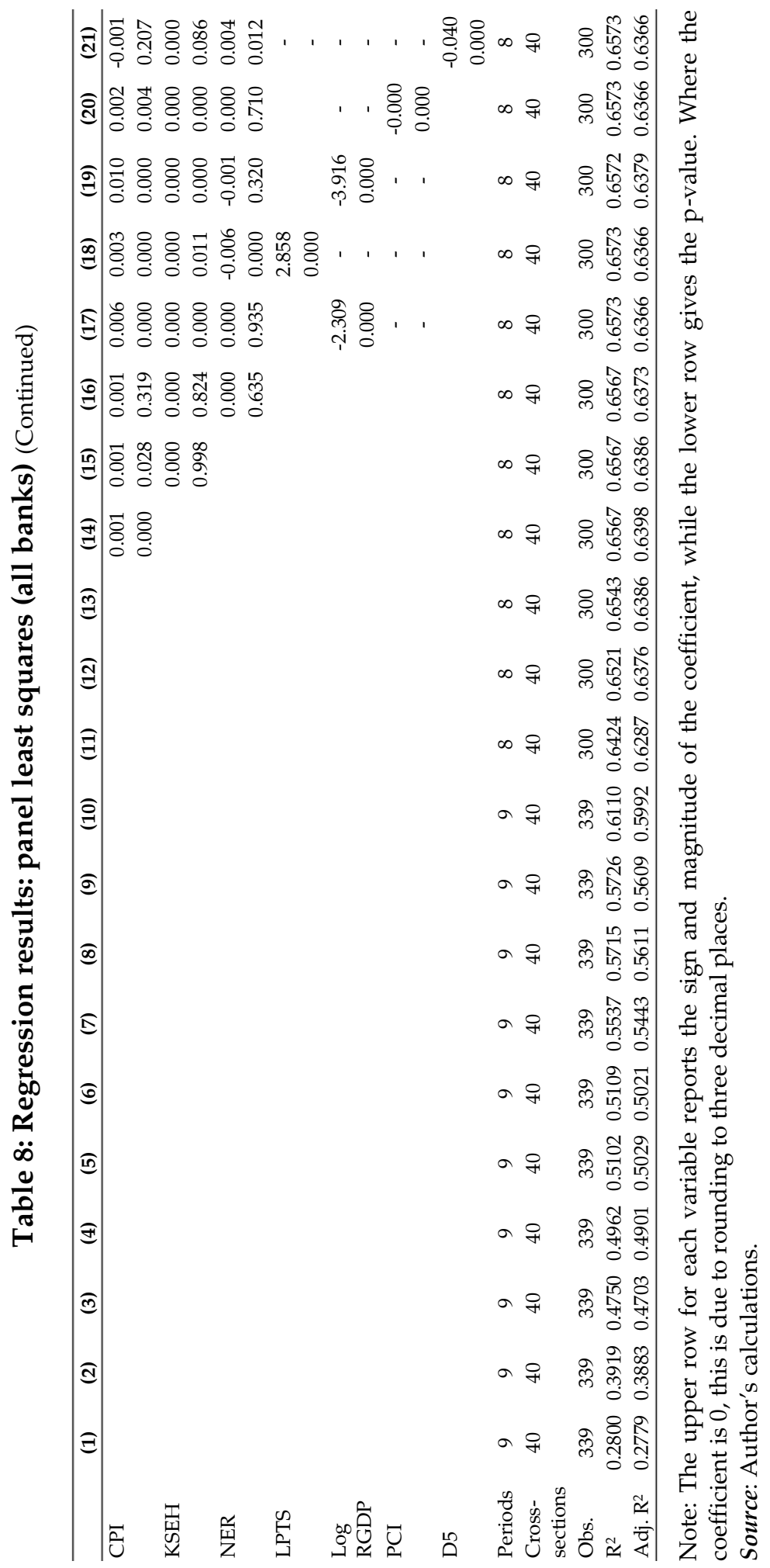




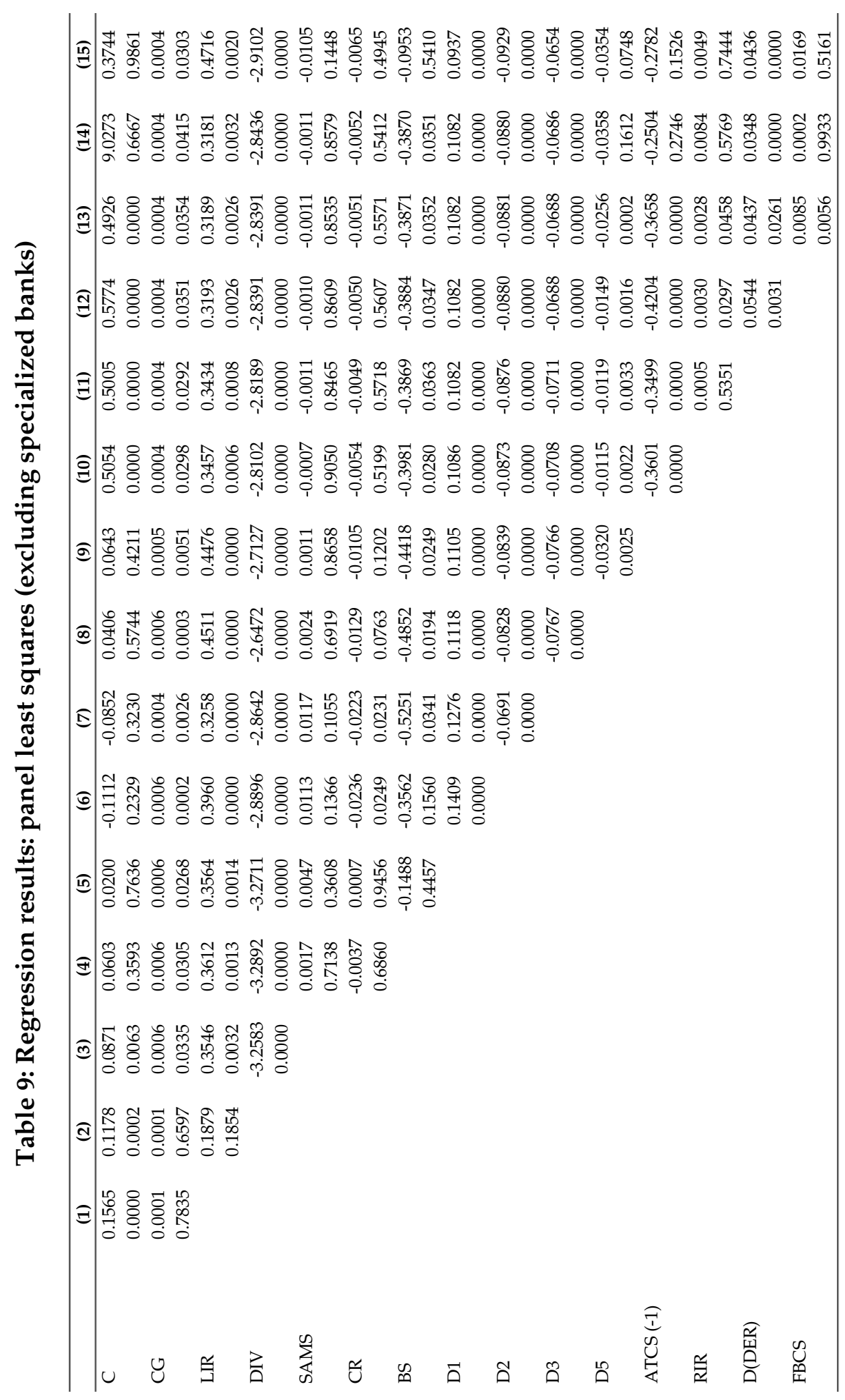




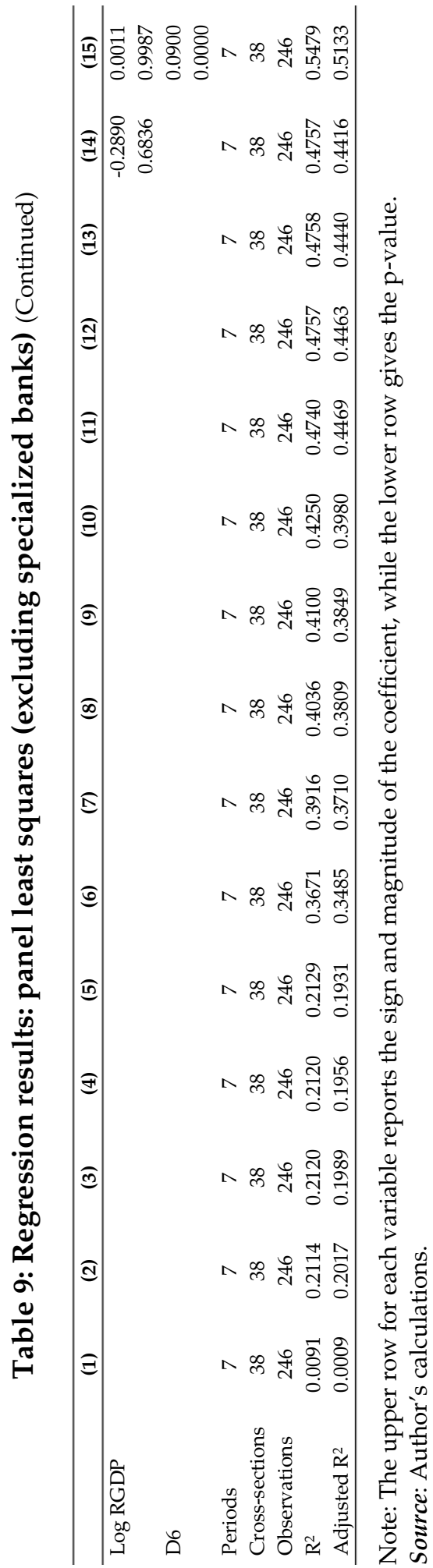


Table 10: Regression results: FE model

\begin{tabular}{llllllll}
\hline & \multicolumn{1}{c}{$\mathbf{1}$} & \multicolumn{1}{c}{$\mathbf{2}$} & \multicolumn{1}{c}{$\mathbf{3}$} & \multicolumn{1}{c}{$\mathbf{4}$} & \multicolumn{1}{c}{$\mathbf{5}$} & \multicolumn{1}{c}{$\mathbf{6}$} & \multicolumn{1}{c}{$\mathbf{7}$} \\
\hline C & 0.1007 & 0.1106 & 0.1241 & 0.1253 & 0.1697 & 0.2376 & 0.8007 \\
& 0.0001 & 0.1729 & 0.1105 & 0.1173 & 0.0086 & 0.0014 & 0.0067 \\
NPLGA (-1) & 0.4536 & 0.4516 & 0.3915 & 0.3527 & 0.3488 & 0.3345 & 0.3158 \\
& 0.0043 & 0.0054 & 0.0191 & 0.0333 & 0.0339 & 0.0407 & 0.0460 \\
CCM & & -0.0185 & -0.0396 & -0.0306 & -0.1119 & -0.1179 & -0.0591 \\
& & 0.8883 & 0.7606 & 0.8168 & 0.2621 & 0.2443 & 0.6275 \\
LIR & & & 0.0192 & 0.0235 & 0.0221 & 0.0220 & 0.0194 \\
& & & 0.0525 & 0.0012 & 0.0043 & 0.0041 & 0.0055 \\
DIV & & & & -1.6211 & -1.6576 & -1.6256 & -1.6316 \\
& & & & 0.0000 & 0.0000 & 0.0000 & 0.0000 \\
CR & & & & & -0.0512 & -0.0503 & -0.0408 \\
& & & & & 0.0026 & 0.0019 & 0.0100 \\
BS & & & & & & -2.3295 & -0.6726 \\
& & & & & & 0.0001 & 0.5098 \\
SAMS & & & & & & & -0.0430 \\
& & 8 & 8 & 8 & 8 & 8 & 8 \\
Periods & 8 & 40 & 40 & 40 & 40 & 40 & 40 \\
Cross-sections & 40 & 299 & 299 & 299 & 299 & 299 & 299 \\
Observations & 299 & 299 & & & & \\
R $^{2}$ & 0.7750 & 0.7750 & 0.7873 & 0.8026 & 0.8061 & 0.8085 & 0.8187 \\
Adj. R & 0.7328 & 0.7318 & 0.7454 & 0.7628 & 0.7661 & 0.7680 & 0.7795 \\
\hline
\end{tabular}

Note: The upper row for each variable reports the sign and magnitude of the coefficient, while the lower row gives the p-value.

Source: Author's calculations.

The positive and significant coefficient (at a 5 percent confidence level) of the public ownership dummy across all specifications corroborates the common perception. It is interesting to note that NPLs are significantly (at a 1 percent confidence level) and negatively associated with the dummy for Islamic banks. The coefficient of the foreign bank dummy is insignificant at conventional levels, and that of the dummy for specialized banks is positive and significant (at a 1 percent confidence level).

The negative and significant coefficient (at a 1 percent confidence level) of asset utilization signifies that a decline in asset turnover damages the ability of the corporate sector to repay its debts, thus raising the NPL level. This implies that the utilization of corporate assets is far more important than merely expanding the asset base through debt financing to repay bank loans. 
Consistent with the findings of Hussain (2012), the study's results suggest that the RIR has a positive and significant impact (at a 5 percent confidence level) on NPLs across all specifications. The financial burden and DER of the corporate sector also have a significant (at 1 percent) and positive effect on NPLs. Larger loans indicate a higher DER, which raises the magnitude of NPLs. It also implies that larger loans are more likely to become NPLs and vice versa - a finding that reflects the data presented in Figure 7, where those sectors that account for the largest shares of bank lending also have higher NPLs (with the exception of commodities).

Figure 7: Gross advances and NPLs, by sector

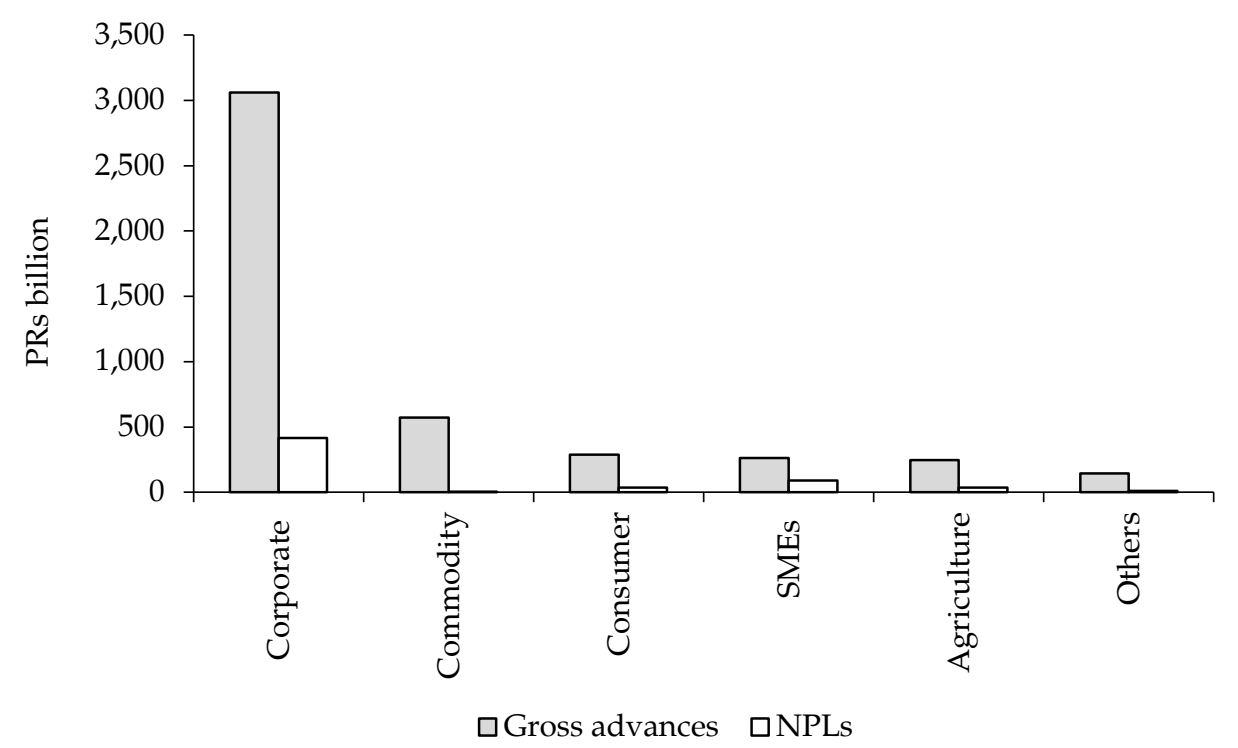

Source: Author's calculations based on data from the State Bank of Pakistan.

Consistent with the findings of Klein (2013), a higher cost of living affects the ability of borrowers to repay their loans: the variable has a positive, significant (at 5 percent) and stable coefficient across all specifications. Although stock price movements have a positive, if very small impact on NPLs (coefficient $=0.0000031$ ), the statistical significance of the coefficient is not robust across all specifications - this finding contradicts Beck et al. (2015). While there is insufficient data to generate evidence, one might expect upward stock price movements to lead to higher expected stock prices, which could motivate investors to borrow further and divert their cash flows toward investment in stocks instead of loan repayment, especially where loan terms are poorly enforced. 
The impact of movements in the exchange rate is insignificant. An adverse macroeconomic environment (a lower real GDP growth rate) raises NPLs and vice versa. This finding is consistent with Klein (2013), Messai and Jouini (2013), Beck et al. (2015) and Anastasiou et al. (2016). It is worth noting that the share of bank lending channeled to the textiles sector (and the fact that this share has increased) has a significant and positive impact on NPLs. This can be interpreted as a positive association between political connectedness or influence and NPLs.

With a few exceptions, the study's results remain largely the same when we exclude specialized banks with an NPL rate of 100 percent. Credit growth, whether measured as a proportion of gross advances or of total assets, or simply as the growth of gross advances, has a positive and significant effect on NPLs regardless of whether the sample includes specialized banks (Tables 8 and 9). This also holds for the impact of bank diversification, bank ownership, corporate asset turnover, corporate financial leverage (the DER) and the global financial crisis. Figure 8 illustrates the significant and positive impact of the share of bank lending to the corporate sector on the NPL rate (see also Table 9).

Figure 8: Credit share, by sector

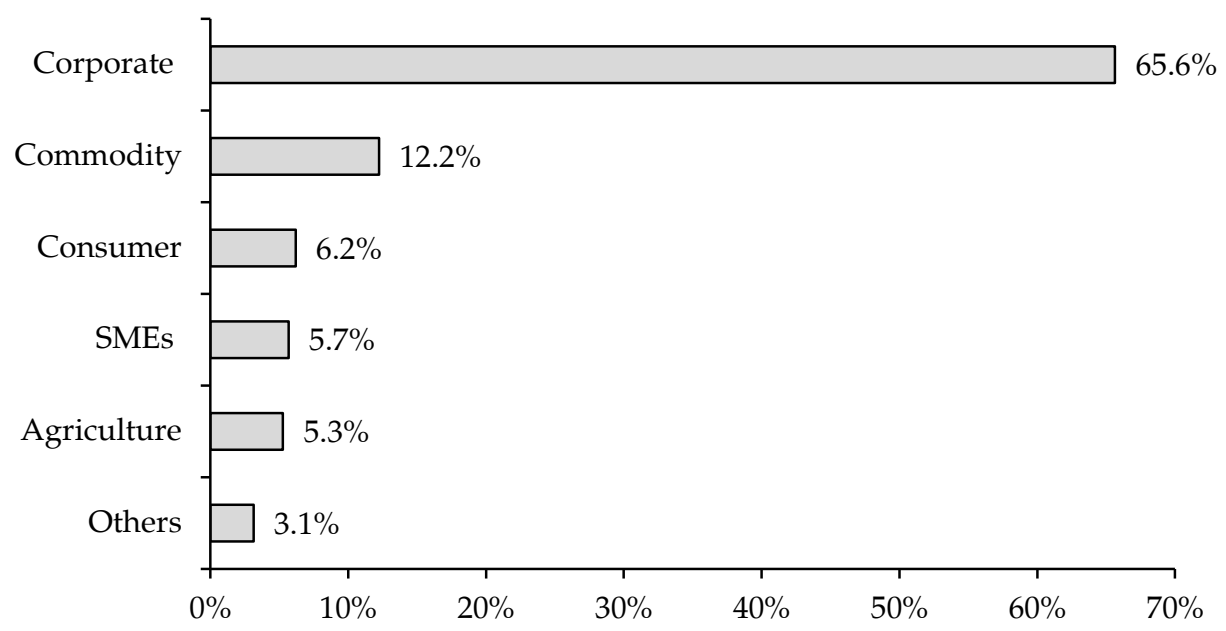

Source: Author's calculations based on data from the State Bank of Pakistan.

The results of the FE model show that the coefficients of bank diversification, the capitalization ratio, bank size and the scale of loan appraisal and monitoring are negative and significant, while the feedback effect of previous NPLs and the lending interest rate are significant and positive. However, the impact of credit growth on NPLs is insignificant. The 
sign and significance of most of the bank-specific variables are robust across the two models, with the exception of bank size and credit growth.

\section{Conclusion and Policy Implications}

The regression results suggest that credit market concentration or credit growth, the lending rate, the cost of living, the bank's market power (bank size), public sector ownership, specialized banking, the DER and financial burden have a positive and significant impact on NPLs. The diversification of bank activities, the scale of loan appraisal and monitoring, Islamic banking, corporate asset turnover and a favorable macroeconomic environment significantly reduce the NPL rate. Stock price movements have a very small positive (0.0000031) effect that is significant across some, but not all, specifications. The impact of foreign banking and nominal exchange rate movements is insignificant because bank lending to foreign borrowers is negligible.

An important finding is that bank-specific indicators have greater explanatory power with respect to the variation in NPLs than corporate sector indicators. Macroeconomic indicators have the least (almost negligible) explanatory power: their addition to the model has little or no impact on the $\mathrm{R}^{2}$ term. Moreover, the results for the key variables remain similar regardless of whether we include or exclude specialized banks with a 100 percent NPL rate. Finally, the relatively large share of bank lending to the corporate sector clearly increases NPLs.

The study's findings have several policy implications:

- If regulators and policy advisors are to manage the NPL rate better, they need to take into account the relevant corporate sector indicators - in addition to bank-specific and macroeconomic variables - when assessing the vulnerable points of the banking and financial sectors.

- The State Bank of Pakistan should focus on strengthening loan appraisal and monitoring systems, especially in conventional and specialized banking. It also needs to ensure that bank credit penetrates segments other than the corporate sector. This entails limiting the pace of credit growth and loan size in the corporate sector's case, given that (i) its financial burden and DER have a positive effect on NPLs and (ii) larger loans are more likely to become NPLs. Giving banks incentive to diversify their activities could also help reduce the NPL rate. 
- The Competition Commission of Pakistan should take measures to reduce the market power of larger banks by promoting competition in the sector.

- Finally, corporate managers need to diversify bank activities and monitor their asset turnover, capital structure and financial burden in addition to other indicators, especially when lending to corporate entities. 


\section{References}

Adhikary, B. K. (2006). Nonperforming loans in the banking sector of Bangladesh: Realities and challenges. Ritsumeikan Journal of Asia Pacific Studies, 21, 75-95.

Anastasiou, D., Lourie, H., \& Tsionas, M. (2016). Determinants of nonperforming loans: Evidence from Euro-area countries. Finance Research Letters, 18, 116-119.

Beck, R., Jakubik, P., \& Piloiu, A. (2015). Key determinants of nonperforming loans: New evidence from a global sample. Open Economies Review, 26(3), 525-550.

Beck, T., Demirgüç-Kunt, A., \& Merrouche, O. (2013). Islamic vs. conventional banking: Business model, efficiency and stability. Journal of Banking and Finance, 37(2), 433-447.

Berger, A. N., \& DeYoung, R. (1997). Problem loans and cost efficiency in commercial banks. Journal of Banking and Finance, 21(6), 849-870.

Berger, A. N., \& Udell, G. F. (2004). The institutional memory hypothesis and the pro-cyclicality of bank lending behavior. Journal of Financial Intermediation, 13(4), 458-495.

Bernanke, B. S., \& Lown, C. S. (1991). The credit crunch. Brookings Papers on Economic Activity, 2, 205-247.

Boudriga, A., Taktak, N. B., \& Jellouli, S. (2010). Bank-specific, business and institutional environment determinants of banks' nonperforming loans: Evidence from MENA countries (Working Paper No. 547). Giza, Egypt: Economic Research Forum.

Çifter, A. (2015). Bank concentration and nonperforming loans in Central and Eastern European countries. Journal of Business Economics and Management, 16(1), 117-137.

De Bock, R., \& Demyanets, A. (2012). Bank asset quality in emerging markets: Determinants and spillovers (Working Paper No. 71). Washington, DC: International Monetary Fund.

Eisenbeis, R. A. (1997). Bank deposits and credit as sources of systemic risk. Economic Review (Federal Reserve Bank of Atlanta), 82(3), 4-19. 
Espinoza, R., \& Prasad, A. (2010). Nonperforming loans in the GCC banking system and their macroeconomic effects (Working Paper No. 224). Washington, DC: International Monetary Fund.

Fernández de Lis, S., Pagés, J. M., \& Saurina, J. (2001). Credit growth, problem loans and credit risk provisioning in Spain. In Marrying the macro- and micro-prudential dimensions of financial stability (vol. 1, pp. 331-353). Basel: Bank for International Settlements.

Glen, J., \& Mondragón-Vélez, C. (2011). Business cycle effects on commercial bank loan portfolio performance in developing economies. Review of Development Finance, 1(2), 150-165.

Hussain, I. (2012). Growth, corporate gearing and nonperforming loans in Pakistan. International Journal of Applied Business and Economic Research, 10(2), 255-267.

Islam, M. A., Karim, L., \& Islam, M. R. (2014). A comparative study of prudential regulation on loan classification and provisioning of the Southeast Asian countries. Journal of Management Research, 6(1), 25-51.

Kauko, K. (2012). External deficits and nonperforming loans in the recent financial crisis. Economics Letters, 115(2), 196-199.

Keeton, W. R. (1999). Does faster loan growth lead to higher loan losses? Economic Review (Federal Reserve Bank of Kansas City), 84(2), 57-75.

Khemraj, T., \& Pasha, S. (2009, May). The determinants of nonperforming loans: An econometric case study of Guyana. Paper presented at the $3^{\text {rd }}$ Biennial Conference on Business, Banking and Finance, Caribbean Centre for Money and Finance, St Augustine, Trinidad.

Klein, N. (2013). Nonperforming loans in CESEE: Determinants and impact on macroeconomic performance (Working Paper No. 72). Washington, DC: International Monetary Fund.

Kwan, S., \& Eisenbeis, R. A. (1997). Bank risk, capitalization and operating efficiency. Journal of Financial Services Research, 12(2-3), 117-131.

Louzis, D. P., Vouldis, A. T., \& Metaxas, V. L. (2012). Macroeconomic and bank-specific determinants of nonperforming loans in Greece: A comparative study of mortgage, business and consumer loan portfolios. Journal of Banking and Finance, 36(4), 1012-1027. 
Messai, A. S., \& Jouini, F. (2013). Micro and macro determinants of nonperforming loans. International Journal of Economics and Financial Issues, 3(4), 852-860.

Podpiera, J., \& Weill, L. (2008). Bad luck or bad management? Emerging banking market experience. Journal of Financial Stability, 4(2), 135-148.

Salas, V., \& Saurina, J. (2002). Credit risk in two institutional regimes: Spanish commercial and savings banks. Journal of Financial Services Research, 22(3), 203-224.

Siddiqui, S., Malik, K. S., \& Shah, S. Z. (2012). Impact of interest rate volatility on nonperforming loans in Pakistan. International Research Journal of Finance and Economics, 84, 66-75.

Woo, D. (2000). Two approaches to resolving nonperforming assets during financial crises (Working Paper No. 33). Washington, DC: International Monetary Fund. 


\section{Appendix}

Figure A1: Impact of low or negative RIR regime on imports of machinery and mechanical appliances, 2006-09

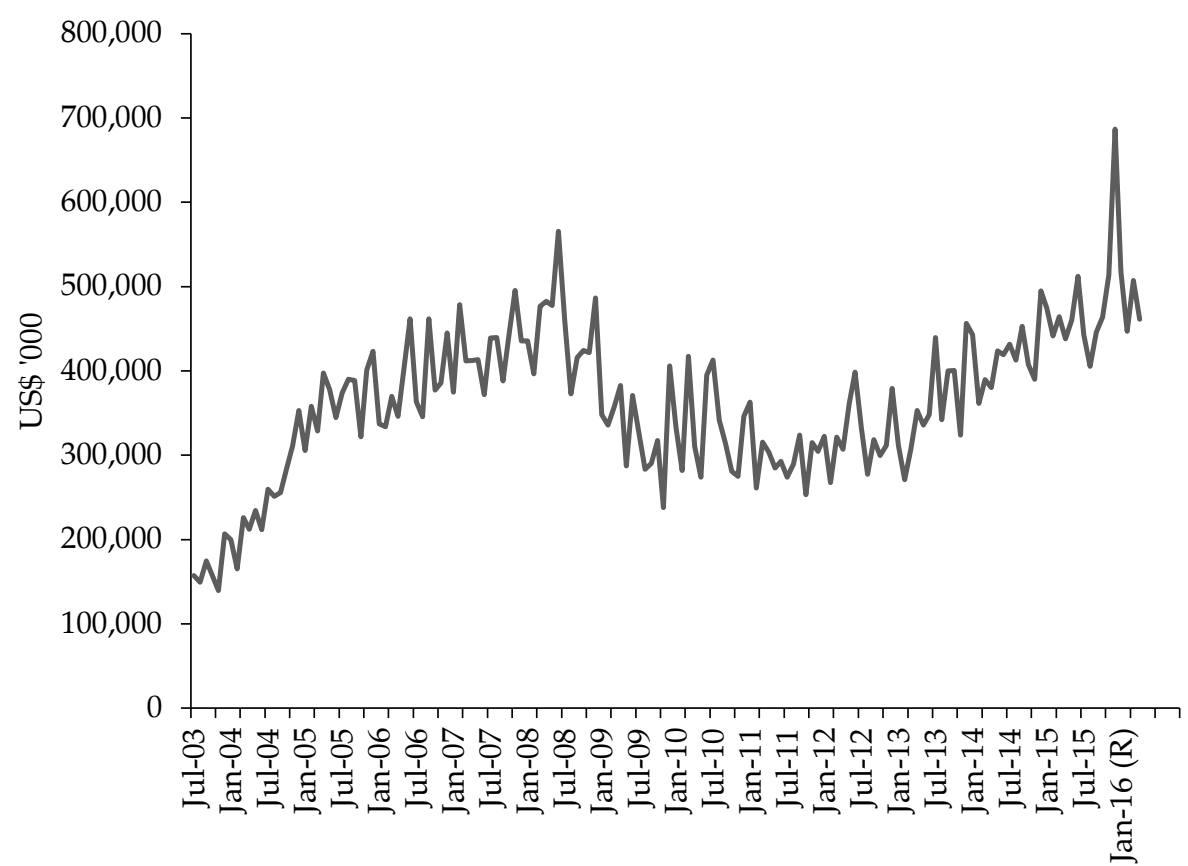

Source: Author's calculations based on data from the State Bank of Pakistan. 